\title{
電界偏向型質量分析計 II \\ Electlical Deflection Type Mass Spectrometer II
}

\author{
兼松 太*, 美馬宏司*, 中井義幸* \\ Futoshi Kanematsu, HiRoshi Mima, YoshiyUKi NaKaI.
}

(1968年10月24日受理)

\begin{abstract}
Performance test of the electrical deflection type mass spectrometer, being proposied in our previous paper, was carried out. Four stage type test tube showed the resolving power of about 6 . On the other hand, if we assume an idealized deflection field and a well-focussed monochromatic ion beam, the resolving power of the tube is estimated to about 60 . The discrepancy between theory and experiment is mainly caused by the following factors.
\end{abstract}

1. Fringing effect of the condenser field

(a) weakening of the deflection field in boundary regions between adjacent condensers.

(b) existense of the electric field component in the direction of tube axis which varies ion's axial velocity which must be constant.

2. Directional distribution of the ion beam.

3. Transit time of the $\mathrm{rf}$ deflection voltage, at the instant of phase inversion.

The effect of the other factors, such as the energy distribution of beam ions which due to the ion source character, the constructional exactness of the electrode system, etc, was found to be sufficiently small in the present stage of experiment.

\section{1.はじめに}

高周波の偏向電界を用いる質量分析計の考案ならび にその理論計算については先に報告した ${ }^{1)}$ 。動作原理 の概略は Fig. 1 (a)に示すごとく平行平板蓄電器を一 列に並べここれらを1つおきに結線して出来上った 2 群A，Bのそれぞれに，（b）図に示すような互いに 逆位相の矩形波電圧を印加し, 初段の蓄電器の電界が 零に変わる瞬間にこれに入射したイオンの中，1区間 ( 1 つの蓄電器あたりの長さ)をちょうど矩形波の半周 期で通過する速度のイオンは途中まったく偏向を受け ることなく直進しコレクター電極に入射検出されると いうものである。理想化された電界を仮定した場合の
分解能 $\rho_{0}$ は

$$
\rho_{0}=\frac{N\left(N^{2}-1\right) l^{2} U_{D}}{48 b d U_{A}}
$$

で与えられる。但し $U_{A}$ はビーム加速直流笔圧, 他の 記号は図中に示されるごとくで前論文 ${ }^{1)}$ に用いたも のである。蓄電器数 Nが或る程度大きくなれば $\rho$ 。は 近似的に $N^{3}$ に比例して增大し高い分解能を得るのに 有利なことが示される。また動作原理からすればハー モニックピークやゴーストピークの現われることもな

く，また台形状のピーク電流を得ることも可能である。 しかしながら実際の製作に当って最も問題となるの はFig. 1 のような理想化偏向電界に近い電界をいか にして作り得るかという点であろう。試作試験の結果

* 大阪市立大学工学部 (大阪市住吉区杉本町)

Faculty of Engineering, Osaka City University (Sugimoto-cho, Sumiyoshi-ku, Osaka) 
(a)
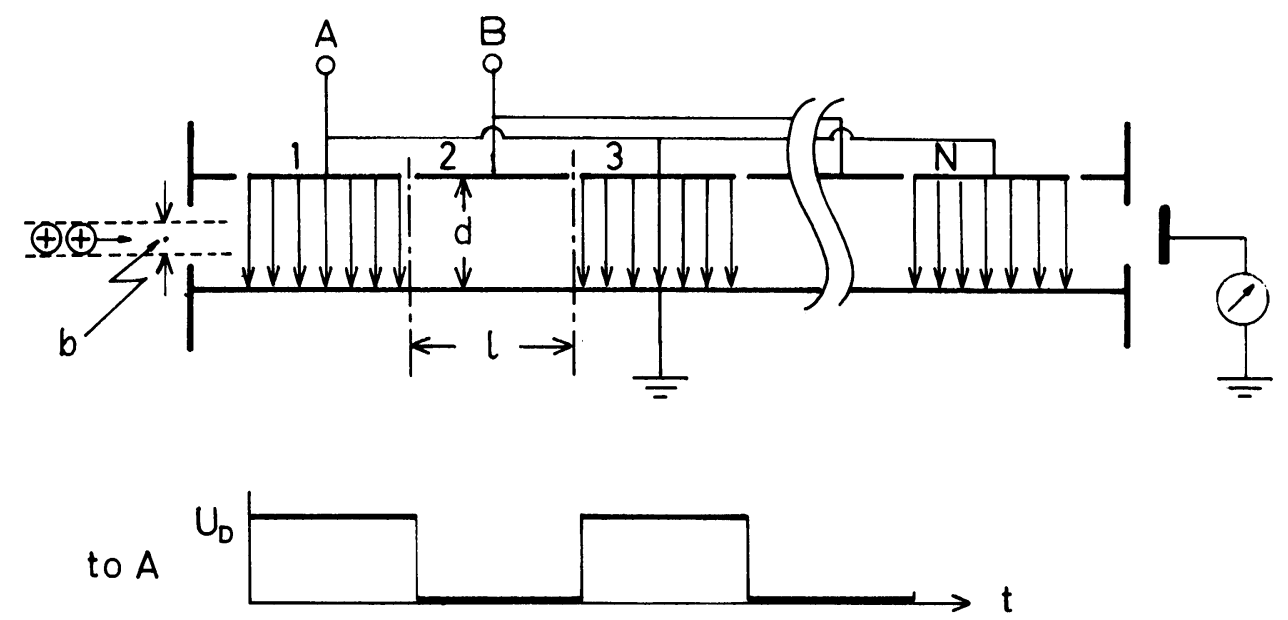

(b) to $B$

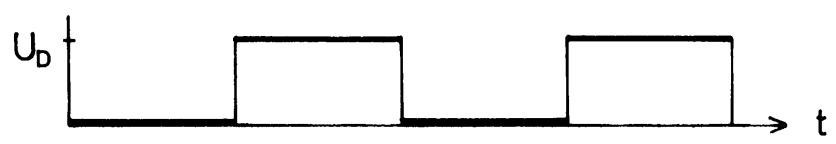

Fig. 1 Principle of the electrical deflection type mass spectrometer.

\section{2. 実験}

\section{1 試作管}

理想笔界に近い偏向笔界を得るための工夫 ${ }^{2)}$ とし ては零暼界の区間への隣接区間からの笔界の漏洩侵入 を防ぐためのシールド板の抑入（Fig. 2 ( a ) ) と,
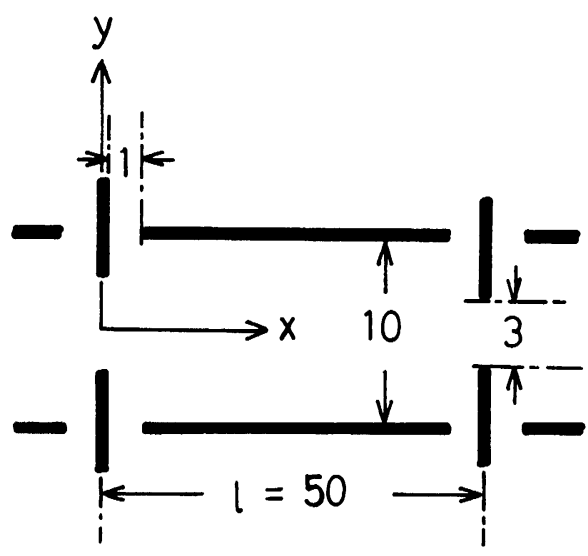

(a)
このシールド板の㨂入に伴う雨区間の境界附近での偏 向電界強度 $E_{y}$ の低下を補うために蓄電器電極の両端 を折曲げた構造（Fig. 2（b ））との 2 種類を具体的 に検討した。便宜上前者を平型電極，後者をL型電極 と呼ぶことにする。いずれの構造を用いるにせよ，隣 接区間の境界領域では縁端効果（電界の漏えい）を免

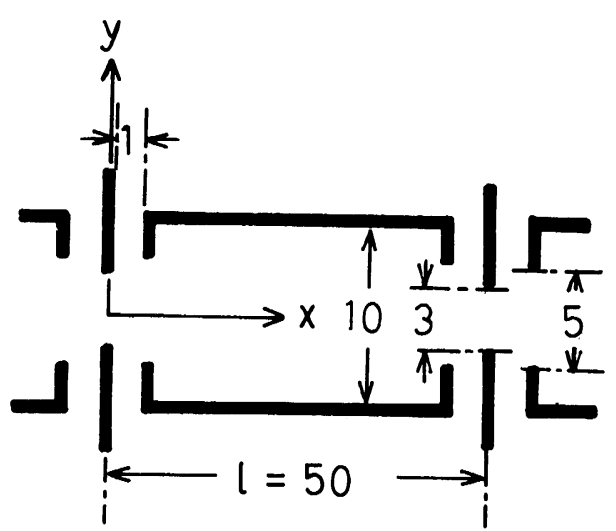

(b)

Fig. 2 Electrode structures, (a) non-bended plate condenser, and (b) L-type bended plate condenser. 
れ得ないため, Fig. 1 の理想的な電界とは異なるも のとなり，撰択されてイオンコレクターに直進すべき イオンにも偏向を加え，また本来一定值を保つはずの イオンの軸方向の速度をも増減することになろう。ま た境界附近での偏向電界 $E_{y}$ の強度低下のため分解能 の低下をもたらすと考えられる。これらの諸効果をそ れぞれ独立に改良することは勿論不可能であるが，そ れらのうち直進すべきイオンの受ける偏向は或る程度 のものなら直流補正電界を加えることによりこれを打 消すことができよう。イオンビームの軸方向速度の変
化や $E_{y}$ の低下をもたらす縁端効果は電極工作精度, 矩形波の波形，イオン源でのエネルギー分布等と共に分解 能を制限する要因であり，本方式に不可避の致命的な欠陥 となる恐れがあるものである。この点を主にして分析 管の性能を調べるべく 4 段型のものを試作した。この 管では L 型の電極構造を採り，各部の寸法は $l=50$ $\mathrm{mm}, \quad d=10 \mathrm{~mm}, \quad b=1 \mathrm{~mm}$ とし, また $U_{\mathrm{D}} / U_{\mathrm{A}}=0.2$ の条件で測定を行った。詳しい構造はFig. 3 に示し てあるが，電界の対称性を考えFig. $2(\mathrm{~b})$ の下半分 を省く工夫を加えたものである。ビームイオンの方向
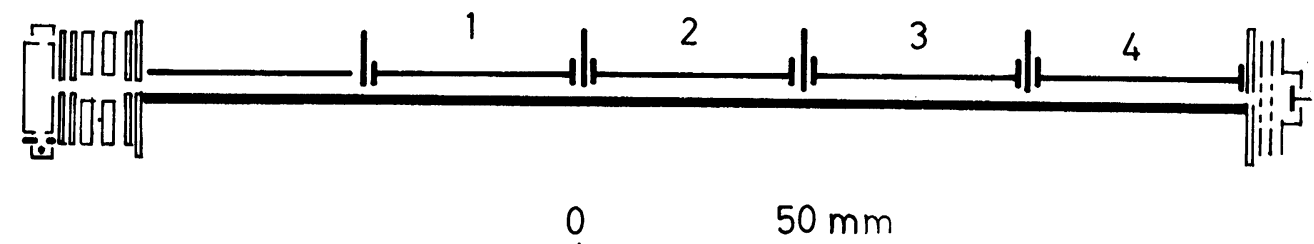

Fig. 3 Structural design of the four stage analysing tube.

分布の影響を出来るだけ避け, 電界の軸方向成分の少 ない上下蓄電器電極板間の中央部を通ったイオン，上 記試作管では映像用シールド板をぬらしながら進むイ オン，だけがコレクターに入射するようにしたもので ある。本方式では偏向を受ける力向に初速度をもった イオンの存在は分解能には全く影響しないが，逆向き の初速度をもつイオンは分解能に有害であるので, こ れを映像用シールド板で除去するようになっている。 イオン源の次に偏向䉓極と同長のコリメーターを配し てあり，管球の全長は約 $30 \mathrm{~cm}$ である。理想化した条 件での分解能は約 60 と計算される。

\section{2 実験結果}

試作管で得られた質量スペクトル例を Fig. 4 に示 す。 $M=18$ と 28 の質量ピークから求めた分解能 $\rho_{0.1}$ は約 6 であった。我感度は約 $3 \times 10^{-9} \mathrm{~A} /$ Torr 程度 で他種の質量分析計に較べ相当低い。”これは原理的 ${ }^{1)}$ に電流効率を高く取れないことにもよるが本実験の場 合イオン源の性能やその取付具合等にもかなり影響さ れており 2 桁程度は改良出来るものと思う。ここで用 いたイオン源は Nier 型の変形で, これによるイオン のエネルギー分布は半值巾 $0.5 \mathrm{ev}$, イオン密度の半值 巾を与える発散角は約 1.5 度のものである。イオンビ 一ムのエネルギー分布にもとずく分解能の低下は少な く, これを考虑して得られる分解能は約53と見積られ

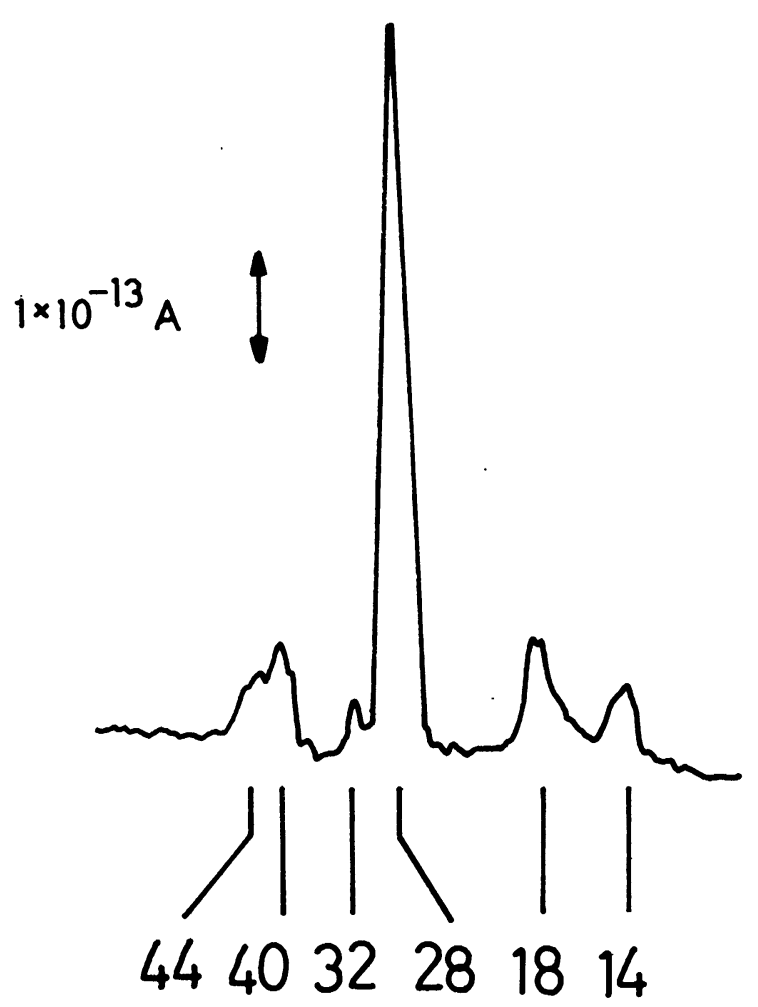

Fig. 4 Spectra of air, $\mathrm{Ar}$ and $\mathrm{CO}_{2}$. Total pressure is $5 \times 10^{-4}$ Torr. 
る。方向分布にもとずく分解能の低下は比較的大きく これは他の分解能低下の原因と共に後章で検討する。

\section{3. 偏向電界の測定とイオン軌道について}

\section{1 偏向電界の測定}

分解能の実験值が理論值と大きく相違する原因を究 明するためには実際の電界について知る必要がある。
Fig. 2（a ）（b ）の電極構造につき，隣接区間との 境界領域すなわちシールド板スリット近傍のコンダク ティングペーパーによる電位分布の測定から求めた。 なお本来の零電位域内の電位分布はこの方法での測定 が困難であったので適当な境界条件を与えてランダム ウォーク法により求めた。これらの結果をFig. 5 (a), (b), ( c ) に示す。

(a)
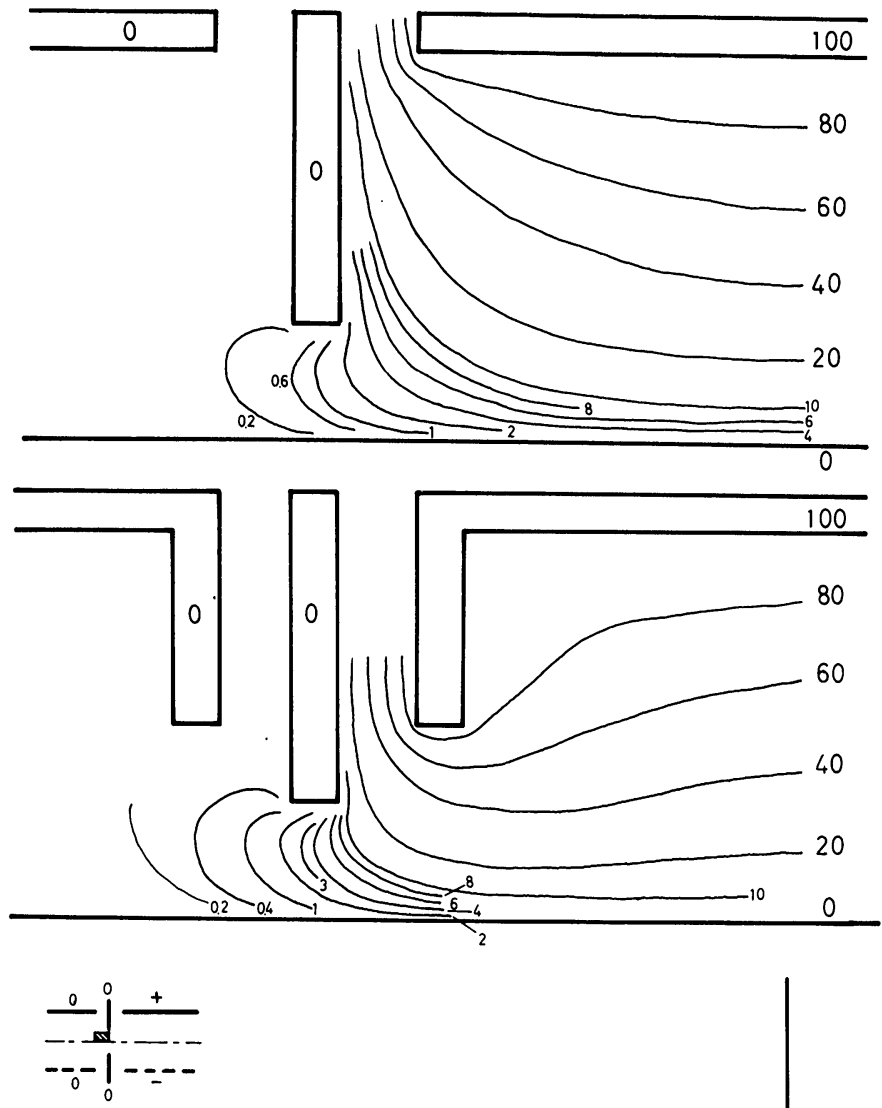

(c)

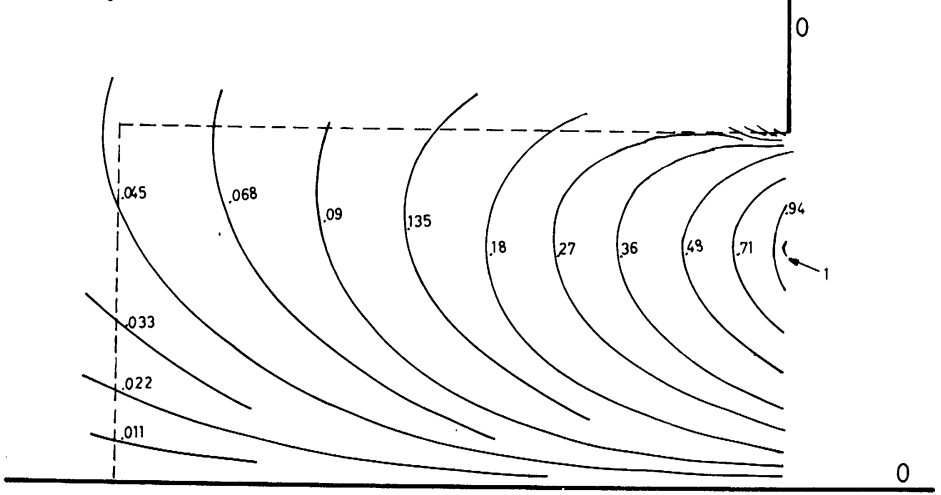

Fig. 5 Equipotential contours between condenser plates, fields are shown in their upper half in each case. (a) non-bended plates, (b) L-type bended plates, and (c) zero field region. 


\section{電界偏向型質量分析計 II}

これをもとに電極軸平面上附近の $\mathrm{y}=0.25,0.75,1.25$ $\mathrm{mm}$ の 3 つの位置での電界分布を求め理想的な場合を 基準にして表わしたものを Fig. 6 （ a ），（b ），（c）， に示す。

\section{2 イオン軌道について}

各段間のスリット近傍における, かかる電界の本来直 進すべきビームイオンの軌道に対する影響を，近似計
算によ一てて求めた結果 ${ }^{5}$ ) を平型電極構造の場合につ き Fig. 7 に示す。これによれば，ある範囲のイオン に限定すれば，むしろ集束効果をも得られることも観 察される。L型電極の場合も，Fig. 6 に見られるご とく偏向電界の様子は平型のそれと類似したものであ るので，電界強度の相違のみを考虑すればよく平型の 場合より少ない段数でほぼ同様の偏向軌跡が得られる

(a)

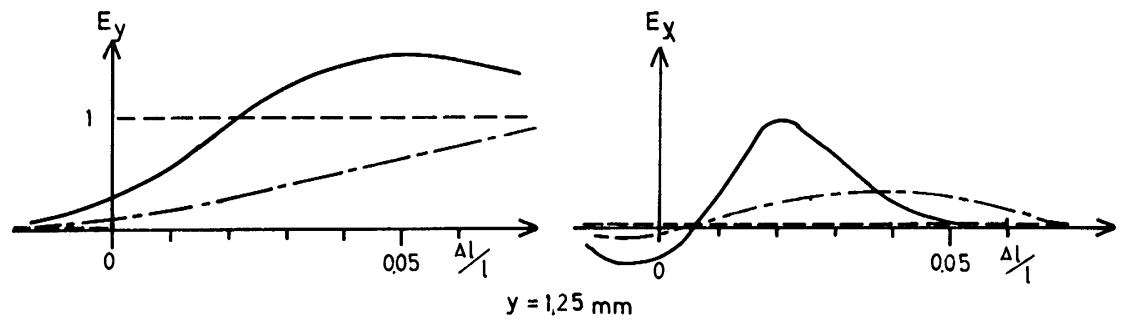

(b)

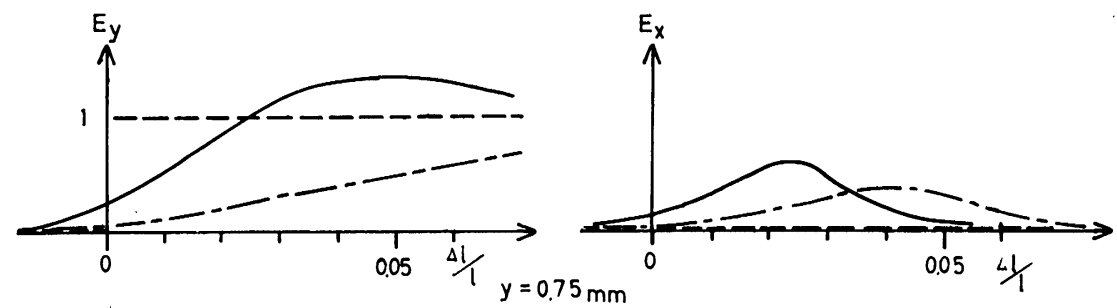

(c)

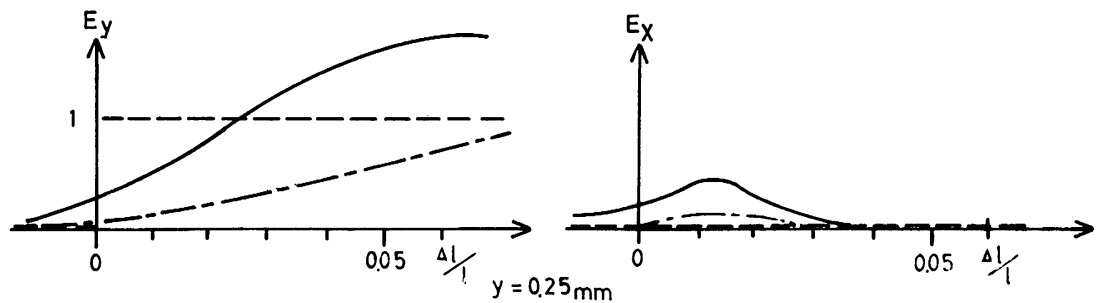

Fig. 6 Electric field intensity distribution along the ion beam axis (a) at $y=1.25 \mathrm{~mm}$, (b) at $y=0.75 \mathrm{~mm}$ and (c) at $\mathrm{y}=0.25 \mathrm{~mm}$.

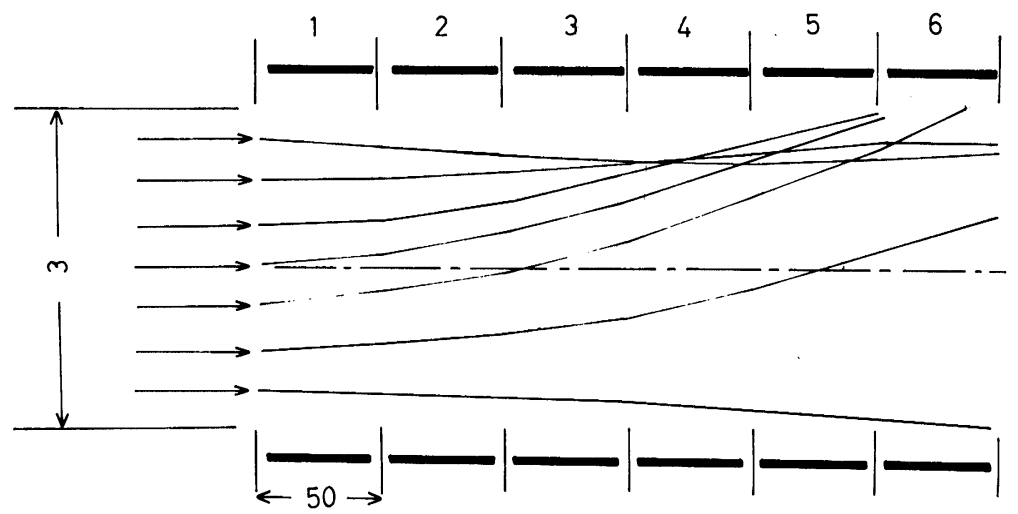

Fig. 7 Ion trajectory affected by the fringing fields near the shielding slit. Under the ideal electric field distribution, the paths should be straight and be parallel in each other. 
と考えられる。質紫が $m_{0}$ からずれた任意の入射位相 のイオンについては，それぞれの軌道の厳密な解析は 尌算機を用いないとほとんど不仃能であるがここで必要 なのはむしろ縁端効果の分解能への影響である。そこ で近軸部分に限定されたイオンビームについてのみ考 えることとし, Fig. 6 (c) の如き電界の作用を受け るものとして分解能を見積り, 理想化笔界の場合の分 解能との関係につき次のごとく兒積りを行った。

\section{3 電界のなまりを考慮した分解能}

$E_{x}$ によるイオンの速度変化は $E_{y}$ による偏向にも 影響する筈であるがそれを考虑に入れた計算は極めて めんどうである。ここではそれぞれの留界成分の効果 を独立に見䄼ってみる。

例えば撰択されるべきイオン $m_{0}$ より軽いイオンが 経験する $\mathrm{y}$ 方向の電界について考えてみると理想化電 界の下ではFig. 8 ( a ) のごとき㳙界を経験するはず

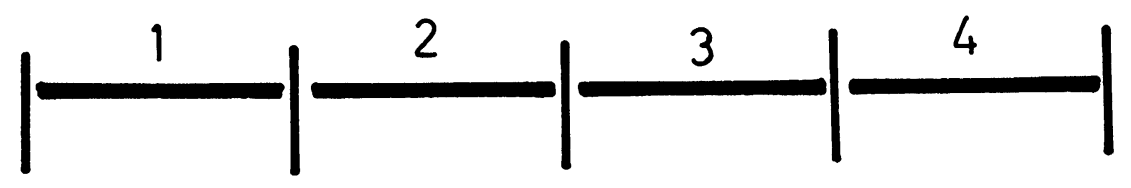

(a)

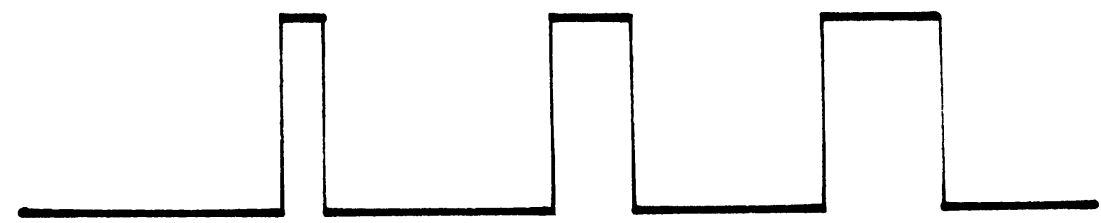

\section{$\Delta l \quad 2 \Delta l \quad 3 \Delta l$}

(b)

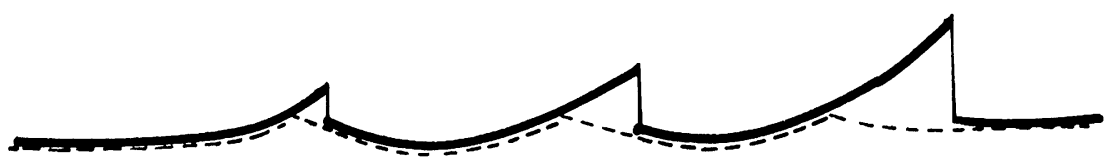

(c)

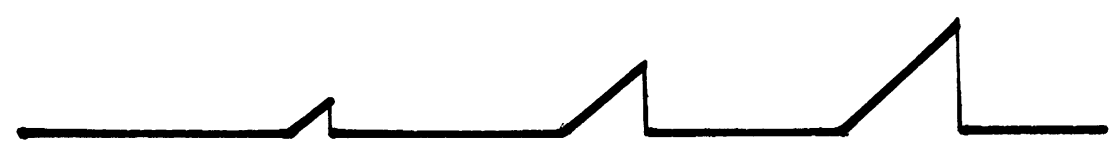

Fig. 8 Electric field that deflects ion of mass $m_{o}-\Delta m$, (a) ideal deflection field, (b) experimental field (c) triangular shaped deflection field used in the calculation of resolving power.

であるが，笑際に経験するのは（b）図に示した䉓界 である。この電界のうち点線で描いた成分は質量 $m_{0}$ のイオンも共に経験する成分である。犋量分離に必要 なのは質步 $m$ 。のイオンと，これと質量が $\triangle m$ だけ 異るイオンの各々が受ける全偏向の差であるから（b） 罒に示した熋界の占線で示した成分を除いた残りの笔 界により分解能が与えられることになる。この波形を (c) 図に示吉三觕波で近似して得られる分解能 $\rho$ と （a）図の場合に得られる分解能 $\rho$ 。の関係を Fig. 9 に示す。但し平型，L型それぞれの場合で分解能 $\rho$ が12，17より低い部分ではここで用いた近似では非常 に不正確なものとなってしまうので各場合につきそれ ぞれ見積りを行わないといけない。同図では，笔極棈 造が平型，L型いずれの場合に於ても得られる分解能 $\rho$ は理想電界の下での值 $\rho$ 。の 3 乗根に比例すること が分かる。 


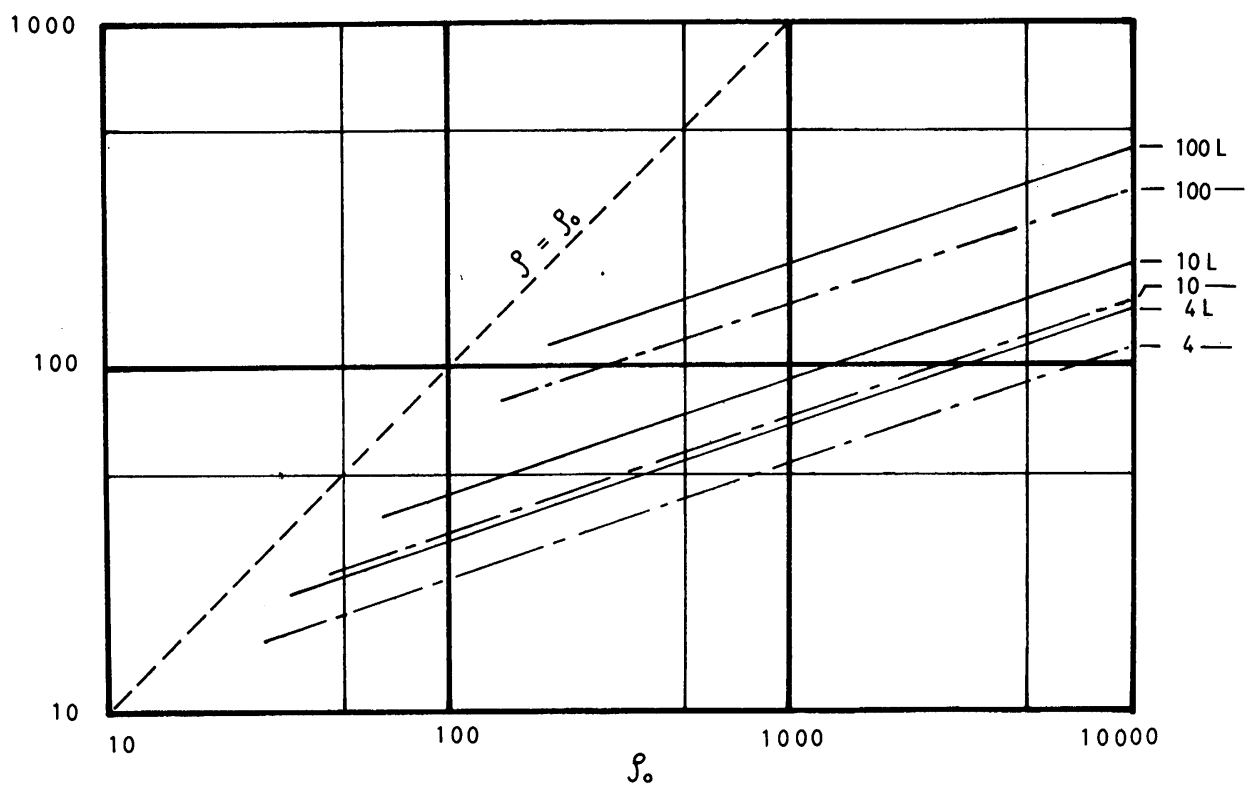

Fig. 9 Resolving power $\rho_{o}$ by idealized deflection field distribution and $\rho$ by triangular shaped deflection field in Fig. 8 (c).

- - - $\ldots$ for ideal case,

for Lrtype bended electrode

arabic numerals mean stage number of $\mathrm{N}$.
次に偏向電界の $\mathrm{x}$ 成分が単色エネルギーのイオンビ 一ムに与える影響を調べると分解能が約50以上の場合 には偏向電極の第 $\mathrm{n}$ 段目においてこの原因によるイオ ンビームのエネルギーの拡がり $\triangle U_{\mathrm{A}}{ }^{\prime}$ はビームの厚 みが $1 \mathrm{~mm}$ のとき平型で $\left|\triangle U_{\mathrm{A}}{ }^{\prime}\right| \leqq\left|\frac{2}{100} U_{\mathrm{D}} \Delta \ln \right|$, L型でこの 3 倍程度になる。また上記の值より小さく イオンビームの厚みがシールド板スリット巾より十分 薄いならばエネルギーの拡がり $\triangle U_{\mathrm{A}}{ }^{\prime}$ はたかだか $U_{\mathrm{D}} \frac{\mathrm{b}}{\mathrm{d}}$ でこの值は $\triangle l$ と共に減少する。これらの工 ネルギーの拡がりの分解能への影響はイオン源に由来 するエネルギーの拡がりの場合と似かよった関係で次 のごとく与えられる。

$$
\rho \geq \frac{\rho_{0}}{1+\frac{\Delta U_{\mathrm{A}}{ }^{\prime}}{U_{\mathrm{A}}} \rho_{o}}
$$

本試作管につき以上の点を考虑して分解能を見積つ

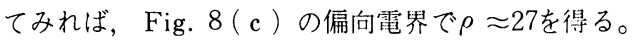
またこれから $\mathrm{E}_{x}$ の影響による減少分をさらに引けば $\rho \approx 15$ という結果が得られる。

\section{4. 考察}

分解能の理論值と実験值との相違は偏向電界の縁端 効果だけからでは十分には説明出来ていないが次のよ うな諸点をも考虑すれば略解決するようである。

\section{1 入射イオンビームの方向分布による分解能の} 低下

大射スリットの上部より斜め下向きに入射してくる イオンのうち大射角度が大きいものは映像電極に衝突 してしまうが或る範囲の入射角度をもつイオンは分析 電極系で上向きの偏向を受けやがて光軸に平行になり 理論計算で用いた入射条件に一致する。したがってこ の位置から後が実効的な分析領域となりこの領域の段 数 $N^{\prime}$ を以って分解能を見積るべきである。Fig. 3 の試作管の場合簡単な見積りにより $N^{\prime}=2 \sim 3$ の範 囲と推定される。この場合偏向電界のなまりを考虑し た分解能の概略值を求めると 4 ～12となる。

この方向分布の悪影響を避けるためにはイオンビー ムの厚みを十分小さくした上これを映像板すれすれに 入射させる方法が教えられる。偏向方向に初速度をも ったイオンは分解能には影響しないが電流効率を低下 
させるにことになろう。またビームの拡がりについて は，その角度が入射スリットからコレクタースリット を見込んだ角度より大きい場合にはピークの形が三角 形となり台形状のピークは得られないという影響が考 えられる。分解能についてのみ考虑を払うこととすれ
ば，静電偏向電極に斜めにイオンビームを入射させる Fig. 10 の如き電極を付加すれば，エネルギーの拡が り $\triangle U_{\mathrm{A}}$ に起因する $\triangle \varphi \approx \frac{\Delta U_{\mathrm{A}}}{2 U_{\mathrm{A}}} \tan \theta$ 程度の方向 分布は残るがこの $\Delta U_{\mathrm{A}}$ を小さくすることにより，方 向分布の半分をほとんど完全に取除くことも叮能であ

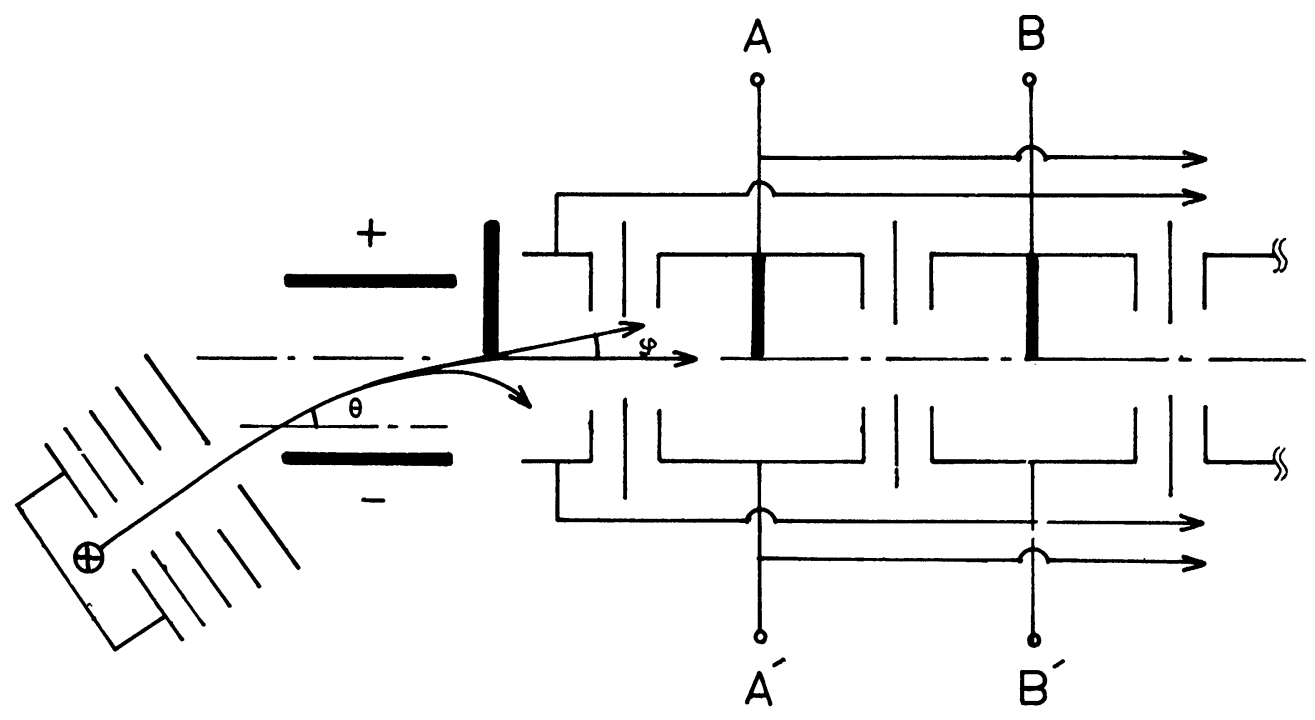

Fig. 10 Improved structure scheme of electrical deflection type mass.

る。なお記㧉験結果はビームの拡がりにより三角状 ピークの場合に相当している。また映像用シールド板 は沙染による帯笓の恐れがあるので Fig. 10 の如く

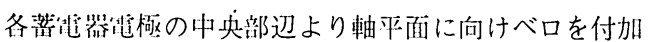
する辢迲のおがよいと思われる。

\section{2 イオンの入射位相の影響}

入射位相の撰択は本来自然に行われる方式であるが， 撰択されるイオンより軽いイオンでちょうど矩形波が 切換わる瞬間に第 1 段と第 2 段の境界に到達するよう な位相で入射したイオンは，両区閒の電極内では全く 偏向を受けないことになる。したがってN 段の分析計 の有効段数は $(\mathrm{N}-1)$ 段と見做さねばならない。こ の原因に基づく分解能の低下を防ぐには Fig. 10 のよ うに第 1 段目の笔極の前に第 2 段目と同じ位相の矩形 波を加えた補助裂極を付加すればよい。この電極の長 さは 1 区間の数分の 1 で十分であろう。

\section{3 矩形波の立上り，立下り時間の影響}

波形のなまりはシールド板スリット付近の笔界閾の なまりと问様に分解能の低下をもたらす。矩形波の周 波数はこの答験の場合 $1 \mathrm{MHz}$ 以下であり技術们に䦌 题はないが，分析㖕の偏向笔極が 1 段当り約 $40 \mathrm{pF}$ の 容卓性負荷となる。立上り或いは立下り時間 $\mathrm{t}_{r}$ が問
題とならぬ分解能の範囲は $\rho \ll \frac{T}{2 \mathrm{t}_{r}}$ で与えられるが 例えば $\mathrm{t}_{r}$ が10 nsec 程度の矩形波をこの容是性負荷 の場合に得るのはかなり困難を伴う。ただ質㠫の大き い所では周期 $\mathrm{T}$ も大きなるので $\mathrm{t}_{r}$ の影響は多少軽 減されることになる。この笑験の場合動作状態での $\mathrm{t}_{r}$ は約 $100 \mathrm{nsec}$ で, 平均的に見て $T / 2 \mathrm{t}_{r} \approx 10$ であるから 分解能にかなりの影響があるものと考えられる。

\section{4 工作精度}

各区間の長さを正確に等しく作ることが重要で，そ の誤差は $l / \rho$ より十分小さくする必要がある。試作 管の場合この要求は十分満されているが，一般的に考 えて比較的容易に製作出来るのは分解能が 100 程度ま でのものと思われる。

\section{5 電極構造の改良法}

以上試作結果を中心に分解能に影響する諸因子につ いて検討した。理論で仮定したような理想化電界は本 来得られないものであるだけに笔極構造の工夫は本力 式にとっての要諦であるが，最後に他に洘えられる留 極構造の例を示す。その一つは Fig. 11（a ）のように 光軸に斜めにメッシュまたはグリッド䒜極を配し軸と 直角な力向の電界成分を分析に利用する方法である。 この方法によると隣接電極間にシールド板を插入した 


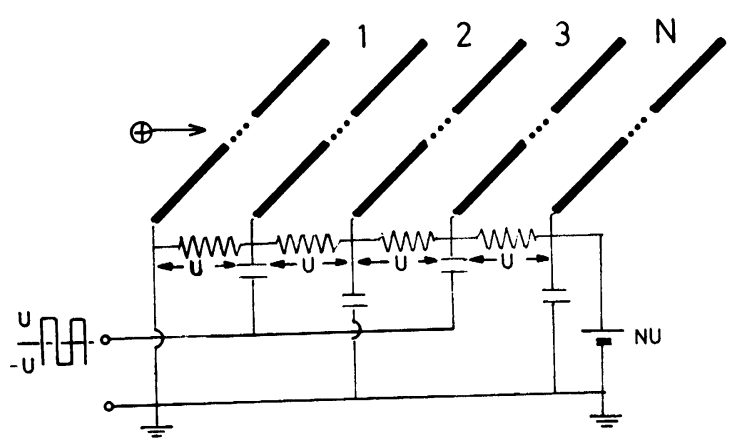

(a)
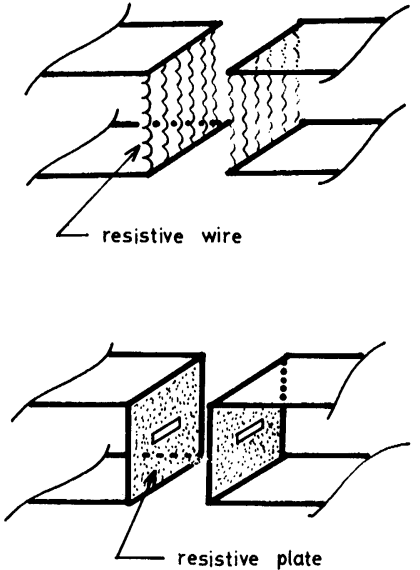

(b)

Fig. 11 Two improved electrode structure proposed.

試作管の方式に較べ電界閾の弱りははるかに少なく電 極間容量も小さく出来る。しかしながら軸方向の電界 成分 $\mathrm{E}_{x}$ がはるかに大きいためイオンのエネルギーの 増減が試作管の方式より激しいため高い分解能は期待 出来ないものである。

もう一つの方法は Fig. 11（b ）のごとく本実験に用 いたシールド板を抵抗線または抵抗膜で置きかえこれ に電流を流した状態で使用することである。しかしな がら構造が複雑となりかつ相当高出力の矩形波発生器 が必要であろう。

\section{5. 結論}

4 段型試作管を中心に実際の性能に影響する諸因子 について検討した。

理想化条件の下では分解能 60 と胃積られるのに対し 実験值は約 6 であった。この分解能の差について検討

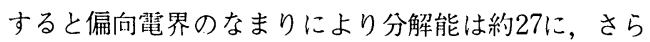
に偏向電界の $\mathrm{x}$ 成分に起因したエネルギー分布の悪化 により約15になることがわかった。イオンビームの方 向分布の影響は映像電極等を用いて改善をはかったが 完全に除くことは出来ず，このために有効段数が減少 して分解能が低下し，また矩形波電圧波形のなまり等 の影響も受け，これらを総合して分解能が実験值にま
で低下したものと考えられる。また偏向方向笔界成分 のなまりの影響のみを考虑した近似計算の結果では, 一般に分解能が理想化電界の場合の值の 3 乗根に比例 することがわかった。

\section{謝辞}

本研究の遂行に当り試作管の作製に御協力いただい た三菱䉓機中研の藤永, 花坂両氏，および寒験を手伝 って下さった本学学生山本, 広瀬両君に本紙面を借り て御礼申し上げる次第である。

\section{文献}

1 ) 兼松，本誌，27昉，131 (1965).

2 ) 兼松·美馬 - 中井他, 質量分析学会第14回年会予 稿, 13 (1966).

3 ) 兼松 · 美馬 - 中井他, 第13回応用物理連合大会予 稿, 80 (1966).

4 ）兼松・美馬・中井他，第 6 回真空に関する連合講 演会予稿，52，(1965)，

H. Mima, Y. Nakai and F. Kanematsu, Mem.

Fac. Eng. Osaka City Univ., 8，225(1966).

5 ) 兼松・美馬 - 中井，第 7 回真空に関する連合講演 会予稿, 75 (1966). 